\title{
SIPRI YEARBOOK 2016
}

SIPRI (Sztokholmski Międzynarodowy Instytut Badań nad Pokojem) systematycznie, od 1969 r., publikuje rocznik poświęcony takim problemom, jak: światowe wydatki zbrojeniowe, międzynarodowe transfery broni, produkcja zbrojeniowa, siły nuklearne, konflikty zbrojne czy multilateralne operacje pokojowe. Zawarte w nim analizy opierają się na aktualnym (najnowszym) stanie wiedzy m.in. z zakresu kontroli broni, pokoju i bezpieczeństwa międzynarodowego. Ostatnie wydanie (Rocznik 2016) dotyczy 2015 r. i koncentruje się na czterech wydaje się najważniejszych z punktu widzenia badań nad pokojem kwestiach: konflikty zbrojne i zarządzanie konfliktami, bezpieczeństwo i rozwój, wydatki wojskowe i uzbrojenie oraz nieproliferacja, kontrola zbrojeń i rozbrojenie. Niniejsze opracowanie, ze względu na objętość SIPRI Yearbook 2016, zawiera uporządkowane chronologicznie najważniejsze tendencje opublikowane w roczniku.

Wprowadzenie w najnowszym wydaniu wpisuje się w trend, przedstawiany we wcześniejszych Rocznikach (2014 i 2015), narastających i niepokojących coraz większą część globu konfliktów oraz przyspieszającej dynamiki zbrojeń. Podkreślono, że rok 2015 nie tylko charakteryzował się ciagłymi i nagłymi zmianami, jak lata poprzednie, ale już należy kwalifikować ten okres jako „szczególnie ciemne lata dla stabilności międzynarodowego porządku i bezpieczeństwa ludzkiego”. Pesymistyczne podejście wynika z dalszego wzrostu liczby konfliktów zbrojnych i ich eskalacji, wraz z wciaganiem w nie coraz większej grupy państw, oraz z niespotykanych wcześniej fal migracyjnych (uchodźczych). Dodatkowym elementem osłabiającym stabilność międzynarodową stały się pogarszające relacje, a nawet wzrost napięcia, członków Paktu Atlantyckiego z Rosją w kontekście Syrii i Ukrainy.

Pozostała część wprowadzenia już bardziej w optymistyczny sposób przedstawia 2015 r., ponieważ podkreśla się w nim stabilizujące znaczenie porozumienia pomiędzy Stanami Zjednoczonymi a Iranem. Uregulowanie irańskiego programu zbrojeń pozwoliło jednocześnie usunąć drażniąca przeszkodę w poprawie polityki bezpieczeństwa na Bliskim Wschodzie, co objawiło się wygasaniem konfliktu w Syrii. Co więcej, w ramach Organizacji Narodów Zjednoczonych udało się wypracować Agendę 2030, w której określa się program zwalczania ubóstwa i działań na rzecz pokoju. Natomiast pod koniec 2015 r. wyznaczono w ramach paryskiego Porozumienia w sprawie zmian klimatu droge postępowania dla społeczności międzynarodowej w kwestii ograniczenia globalnego ocieplenia oraz dostosowania państw do nieuniknionych zmian. Jednak ogólny trend sprzyja tezie o stałym porzuceniu względnego spokoju dwóch ostatnich dekad postzimnowojennego świata ku bardziej zdestabilizowanemu i pełnemu konfliktów okresu. Po 14 latach wojny z terroryzmem (ang. war on terrororism) można 
wysnuć podstawowy wniosek, że pokój narzucany przez podmioty państwowe nie sprzyja międzynarodowej stabilizacji.

Pierwsza część Rocznika SIPRI 2016 obejmuje problematykę konfliktów zbrojnych i zarządzania konfliktami, a dokładniej charakteryzuje opisane wcześniej (we wprowadzeniu) tendencje. Po pierwsze, w 2015 r. wzrasta liczba uchodźców (migrantów), którzy podejmują ryzyko przemieszczenia się między kontynentami w wyniku umiędzynarodowionych wewnętrznych konfliktów, szczególnie w rejonie Bliskiego Wschodu. Po drugie, tzw. Państwo Islamskie kontroluje znaczne terytoria północnego Iraku i Syrii, zaś sam fakt jego funkcjonowania wpisuje się w wieloletnią rywalizację (od 1979 r.) między sunnicką Arabią Saudyjską a szyickim Iranem. Po trzecie, głównymi państwami tranzytowymi dla uchodźców (4 mln Irakijczyków i $12 \mathrm{mln}$ Syryjczyków) stały się Jordania, Liban i Turcja, co w dłuższej perspektywie prowadzi do ich destabilizacji (obniżenie bezpieczeństwa publicznego). Po czwarte, nadal tli się problem kurdyjski, a dokładniej problem niepodległości dla 30 mln Kurdów. Ten naród bez państwa oddziałuje znacznie na konflikt syryjski i iracki, ponieważ wygrywa w starciu z tzw. Państwem Islamskim i zdobywa istotne terytoria, co zwiększyło jego legitymizację w ocenie Zachodu. Dodatkowo te sukcesy militarne uniemożliwiły Turcji ostateczne rozwiązanie problemu kurdyjskiego. Po piąte, w 2015 r. sankcje nałożone na Iran wykraczały poza decyzje ONZ i zastosowano nie tylko zakaz sprzedaży broni i towarów podwójnego zastosowania, ale także wprowadzono bilateralnie sankcje finansowe, handlowe, turystyczne i transportowe. Po szóste, od 1975 r. w co najmniej dwóch trzecich wszystkich konfliktów udział brały podmioty zewnętrzne i ich pomoc polegała na bezpośrednim udziale wojsk lub personelu (doradców) oraz pośrednim wykorzystaniu danych wywiadowczych, wsparcia logistycznego lub finansowego czy szkoleń (treningów). Od 2015 r. widać wyraźny wzrost stosowania narzędzi dyplomacji smart power, szczególnie wojny hybrydowej, co potwierdza się na Ukrainie i w Syrii. Po siódme, po trzech latach podpisano pokojowe porozumienie w Mali, zaś jego głównymi wyzwaniami implementacyjnymi są: złożoność konfliktu, rozdrobnienie zaangażowanych podmiotów, zwiększone występowanie grup ekstremistycznych i wzrost przestępczości zorganizowanej. Po ósme, liczba aktywnych konfliktów zbrojnych wzrosła z 41 w 2014 r. do 50 w 2015 r., głównie ze względu na ekspansję tzw. Państwa Islamskiego na nowe terytoria w 12 krajach. Jednakże poziom przemocy zbrojnej utrzymuje się znacznie niższej niż był w okresie zimnej wojny. Po części dlatego, że wspólnota międzynarodowa opracowała lepsze mechanizmy radzenia sobie z tą właśnie przemocą. 2015 r. był okresem konsolidacji trendu w zakresie misji pokojowych, ponieważ w porównaniu z rokiem ubiegłym rozpoczęto tylko dwie nowe operacje pokojowe. W sumie w 61 operacjach udział brało 162703 pracowników, tj. o 3336 więcej niż w 2014 r.

Druga część Rocznika SIPRI 2016 obejmuje problematykę bezpieczeństwa i rozwoju. Zawarty w niej główny trend sprowadza się do kompleksowego ujęcia prawem działalności na rzecz poprawy jakości życia społeczności obciążonej konfliktem zbrojnym. Wyzwania rozwojowe są szczególnie dotkliwe dla 2,58 miliarda ludzi żyjących w niebezpiecznych miejscach, w państwach o wysokiej zachorowalności, gwałtownej śmierci oraz z dużą liczbą uchodźców. Po pierwsze, przyjmuje się, że informatyzacja (ogólnie technologie informacyjne) zapewnia bezprecedensowy potencjał dla ludzi. 
Nie ma jednak badań na dużą skalę co do rzeczywistego wpływu technologii IT na poprawę jakości życia, ale przede wszystkim na niwelowanie nierówności między Północą a Południem. Co więcej, niewiele wiadomo o wpływie na bezpieczeństwo cybernetyczne, bezpieczeństwo ludzkie i bezpieczeństwo narodowe czy o wzroście przestępczości $\mathrm{w}$ informatyzowanych państwach. Po drugie, bezpieczeństwo było najważniejszym problemem dla Unii Europejskiej w 2015 r., niż miało to miejsce kiedykolwiek w przeszłości, po upadku ZSRR. Sednem były (są): globalna mobilność osób, swobodny przepływ kapitału, rozdrobniony i niedostatecznie regulowany system finansowy, ograniczona zdolność państw do zarządzania zmiennymi, szybki postęp technologiczny oraz zmiany demograficzne i przestrzenne tworzone w wyniku globalizacji, urbanizacji i digitalizacji. Obywatele UE posiadają wysokie oczekiwania i są przyzwyczajeni do swobodnego poruszania się, lecz bez nadmiernej troski o bycie ofiarą brutalnego ataku (przestępstwa) lub zamachu terrorystycznego. Jednakże dwie trzecie respondentów z UE uważa, że będzie doświadczać zwiększonego poziomu terroryzmu i zorganizowanej przestępczości w wyniku ekstremistycznych ideologii. Po trzecie, państwa członkowskie są podstawowymi podmiotami w zwalczaniu zagrożeń o charakterze terrorystycznym, ale UE stała się platformą do wypracowania wspólnych rozwiązań i prowadzenia samego dialogu. Po czwarte, istniejące procedury, indywidualne w każdym państwie unijnym, w czasie ubiegania się o azyl stały się niewydolne $\mathrm{w}$ aspekcie bezprecedensowej masowej migracji. Po piąte, środowisko akademickie potwierdziło negatywny wpływ zmian środowiskowych (klimatycznych) na bezpieczeństwo ludzi (przeżycie), jak np. ekstremalne zjawiska pogodowe zwiększają niepewność egzystencji itp.

W trzeciej części Rocznika SIPRI 2016 zamieszczono analizy z obszaru wydatków wojskowych i uzbrojenia. Po pierwsze, światowe wydatki militarne w 2015 r.szacuje się na 1 bilion 676 miliardów dolarów, co daje 2,3\% światowego produktu krajowego brutto lub $228 \$$ na osobę. Następuje spadek wydatków w Ameryce Północnej i Europie, choć w wolniejszym tempie niż rok wcześniej, w przeciwieństwie do Azji, w tym na Bliskim Wschodzie (w państwach publikujących dane), gdzie wzrasta wolumen zakupów. Po drugie, gwałtownie spadające ceny ropy naftowej zmusiły państwa opierające na niej swój budżet, do równie radykalnego ograniczenia wydatków wojskowych. Po trzecie, nadal zdecydowanym liderem w rankingu zbrojeniowym są Stany Zjednoczone z budżetem na poziomie 596 miliardów dolarów, czyli około 36\% globalnych wydatków. Po czwarte, Chińska Republika Ludowa utrzymuje się w trendzie wzrostowym (zwiększa skalę wydatków militarnych adekwatnie do wzrostu gospodarczego), co sugeruje, że przenosi rywalizację między mocarstwami z lądu na morza. Po piąte, utrzymuje się tendencja spadkowa zamówień wojskowych i nie zanosi się na odwrócenie trendu. Nadal $80 \%$ udziału w rynku należy do Stanów Zjednoczonych i Zachodniej Europy. Po szóste, po konsolidacji firm zbrojeniowych w Polsce, utworzono Polską Grupę Zbrojeniową, wzrost zamówień w tym państwie wyniósł 98,4\%. Po siódme, pięciu największych dostawców broni (USA, Rosja, Chiny, Francja, Niemcy) mają $74 \%$ udział w globalnych zamówieniach. USA i Rosja konsekwentnie od 1950 r. utrzymują swoją pozycję. Dodatkowo 2015 r. okazał się kolejnym rozczarowaniem w kwestii przejrzystości transferów broni. Już tylko nieco ponad $25 \%$ członków ONZ raportowała wielkość eksportu i importu broni, najniższy poziom utrzymuje się 
Wykres 1. Zmiany w wydatkach wojskowych wg regionu w latach 2014-2015

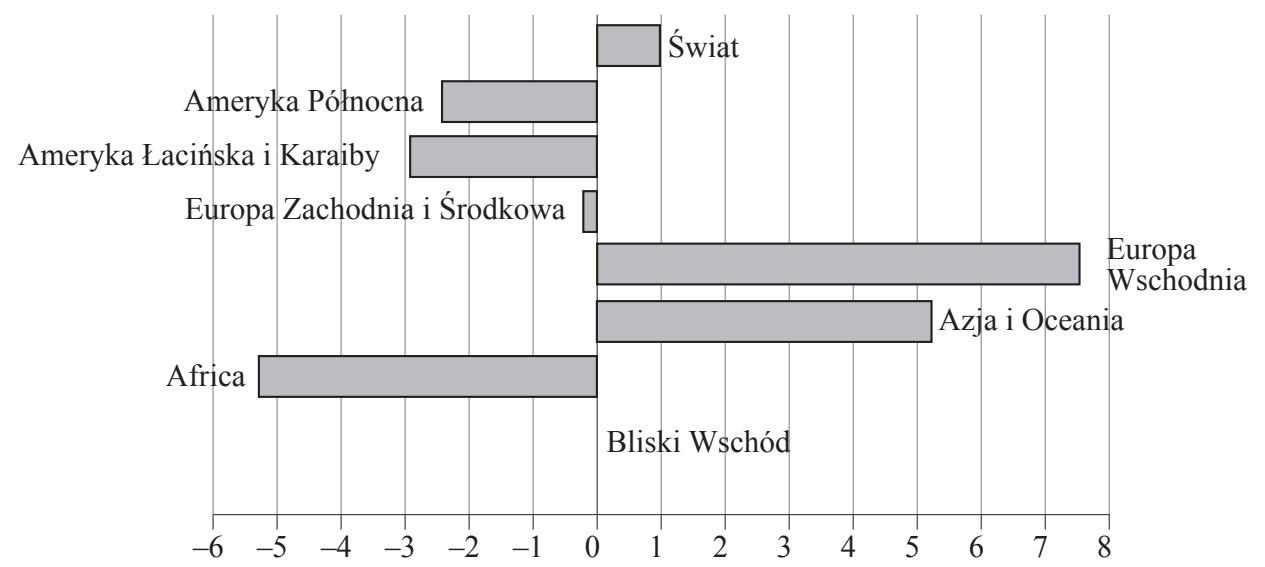

Źródlo: SIPRI Yearbook, 2016: 18.

w Afryce i na Bliskim Wschodzie. Szacuje się, że łączna wartość rocznego transferu wynosi 94,5 mld dolarów, choć prawdopodobnie jest ona wyższa.

Tabela 1

Główni eksporterzy broni w latach 2011-2015

\begin{tabular}{|r|l|c|r|l|c||}
\hline \hline \multicolumn{2}{|c|}{ Exporter } & Global share (\%) & \multicolumn{2}{|c|}{ Importer } & Global share (\%) \\
\hline 1 & USA & 33.0 & 1 & Inde & 14.0 \\
\hline 2 & Rosja & 25.0 & 2 & Arabia Saudyjska & 7.0 \\
\hline 3 & Chiny & 5.9 & 3 & ChRL & 4.7 \\
\hline 4 & Francja & 5.6 & 4 & ZEA & 4.6 \\
\hline 5 & Niemcy & 4.7 & 5 & Australia & 3.6 \\
\hline 6 & Wielka Brytania & 4.5 & 6 & Turcja & 3.6 \\
\hline 7 & Hiszpania & 3.5 & 7 & Pakistan & 3.3 \\
\hline 8 & Włochy & 2.7 & 8 & Wietnam & 2.9 \\
\hline 9 & Ukraina & 2.6 & 9 & USA & 2.9 \\
\hline 10 & Niderlandy & 2.0 & 10 & Korea Południowa & 2.6 \\
\hline
\end{tabular}

Źródło: SIPRI Yearbook, 2016: 20.

Po ósme, na początku 2016 r. dziewięć państw (USA, Rosja, Wielka Brytania, Francja, Chiny, Indie, Pakistan, Izrael i Koreańska Republika Ludowo-Demokratyczna) posiada około 15395 sztuk broni jądrowej, z czego 4120 rozmieszczono, a mniej więcej 1800 utrzymuje się w stanie podwyższonej gotowości operacyjnej. Łączna liczba głowic jądrowych spada w wyniku wynegocjowanych traktatów rozbrojeniowych, ale ogólnie rośnie zdolność operacyjna państw w aspekcie użycia broni atomowej. Korea Północna nadal dąży do pozyskania rakiety balistycznej gotowej do przenoszenia broni atomowej, którą ma już w posiadaniu. Nadal nie jest znana rzeczywista liczba głowic nuklearnych tego państwa oraz zapasów plutonu, również Indii i Izraela. 
W czwartej i ostatniej części Rocznika SIPRI (nieproliferacja, kontrola zbrojeń i rozbrojenie) analizę tej problematyki podporządkowano najważniejszemu, ponieważ przełomowemu, wydarzeniu, czyli wielonarodowemu porozumieniu w sprawie ograniczeń programu nuklearnego Iranu. W nim zdefiniowano narzędzia i procedury monitorowania i weryfikacji działalności irańskiej przez Międzynarodową Agencję Energii Atomowej, aby program atomowy tego państwa utrzymał charakter pokojowy. W efekcie zniesiono sankcje ONZ i w ślad za tą organizacją międzynarodową poszły inne mocarstwa. Niestety nie udało się uzgodnić programu pracy w ramach otwartej grupy roboczej „Promowania wielostronnego rozbrojenia nuklearnego”, w praktyce nie ustalono nawet jednego wspólnego elementu tego programu. W obszarze broni biologicznej i chemicznej utrzymał się trend wzmacniania międzynarodowych zakazów stosowania tego rodzaju broni, zaś w Syrii w styczniu 2016 r. zakończono proces likwidacji toksycznych substancji w tym państwie. W kontekście kontroli zbrojeń mimo różnicy w kluczowych kwestiach odbyła się w Cancun 24-27 sierpnia 2015 r. pierwsza konferencja sygnatariuszy Traktatu o handlu bronią, na której uzgodniono kwestie instytucjonalno-proceduralne, będące podwaliną wykonawczą traktatu (np. określono lokalizację sekretariatu). Nie ma jednak wypracowanych jednolitych standardów działania, także w aspekcie broni i towarów podwójnego zastosowania. Wręcz ten brak sformalizowania zachęca państwa, szczególnie z Bliskiego Wschodu, do nieudzielania informacji z omawianego zakresu aktywności (brak udostępnionej informacji publicznej). Na końcu Rocznika SIPRI, jak corocznie, dołączono aneksy (syntetyczne i chronologiczne).

\title{
STRESZCZENIE
}

Komentarz poświęcono SIPRI YEARBOOK 2016 i zawartym w nim najważniejszym tendencjom potwierdzonych najbardziej aktualną wiedzą. Coroczne opracowanie w kompleksowy sposób ukazuje aktywność aktorów międzynarodowych w kwestii światowych wydatków zbrojeniowych, międzynarodowych transferów broni, produkcji zbrojeniowej, sił nuklearnych, konfliktów zbrojnych czy multilateralnych operacji pokojowych.

Słowa kluczowe: Sztokholmski Międzynarodowy Instytut Badań nad Pokojem, Rocznik SIPRI 2016, zbrojenia, rozbrojenie, bezpieczeństwo międzynarodowe, zarządzanie konfliktami

\section{SIPRI YEARBOOK 2016}

\begin{abstract}
The commentary includes the most important trends confirmed the current knowledge in the SIPRI Yearbook 2016. Every year the organization in a comprehensive manner shows the activity of international actors in terms of world military expenditure, international arms transfers, arms production, nuclear forces, armed conflicts and multilateral peace operations.
\end{abstract}

Keywords: Stockholm International Peace Research Institute, SIPRI Yearbook 2016, Armament, Disarmament, International Security, Conflict Management 
